\title{
Physico-Chemical Status of Eleyele Reservoir, Ibadan, Nigeria
}

\section{Olanrewaju AN ${ }^{1 *}$, Ajani EK ${ }^{2}$ and Kareem $\mathrm{OK}^{2}$}

${ }^{1}$ Federal College of Freshwater Fisheries Technology, Maiduguri, Nigeria

${ }^{2}$ Department of Aquaculture and Fisheries Management, University of Ibadan, Nigeria

\begin{abstract}
Eleyele reservoir is a vital resource for fishery, domestic water supply and flood control. Unfortunately, the reservoir is fast being degraded due to various anthropogenic activities around its catchments. Hence, this study evaluates spatio-temporal variations in the physico-chemical parameters of the reservoir. Eleyele reservoir was stratified into five zones (S1-S5) based on hydrological features and three sampling points were randomly selected per zone. Water samples were collected bi-monthly from each station for 24 months covering wet (May-November) and dry (December-April) seasons. Water parameters were analysed for alkalinity $(\mathrm{mg} / \mathrm{L})$, phosphate $(\mathrm{mg} / \mathrm{L})$, Dissolved Oxygen (DO, mg/L), Biological Oxygen Demand (BOD, mg/L), Chemical Oxygen Demand (BOD, mg/L) and temperature $\left({ }^{\circ} \mathrm{C}\right)$ following standard procedures. Highest and least alkalinity $(103.63 \pm 14.87 ; 96.25 \pm 11.41)$ and phosphate $(2.00 \pm 0.69 ; 1.94 \pm 0.66)$ were recorded in S2 and S4, respectively. Temperature and DO ranged from $26.53 \pm 2.20$ (S5) to $26.86 \pm 2.45$ (S1) and $4.24 \pm 0.84$ (S2) to $5.39 \pm 0.82$ (S5), respectively. Alkalinity were $99.72 \pm$ 12.41 and $100.91 \pm 16.14$, phosphate $(1.71 \pm 0.55 ; 2.10 \pm 0.61)$, temperature $(28.20 \pm 2.34 ; 25.53 \pm 1.74)$ and DO $(4.48 \pm 0.98 ; 4.85 \pm 0.97)$ in dry and wet seasons, respectively. The mean values obtained for Biological Oxygen Demand $\left(4.29 \pm 2.23 \mathrm{mgl}^{-1}\right)$, temperature $(26.64 \pm 2.36)$, conductivity $\left(0.270 \pm 0.21 \mu \mathrm{Scm}^{-1}\right)$, alkalinity $(100.42 \pm$ 14.69), hardness $\left(69.18 \pm 30.94 \mathrm{mgl}^{-1}\right)$ and ions were within desirable limits for aquatic life. Crucial steps should be taken to reduce agricultural activities and anthropogenic discharges into the Reservoir.
\end{abstract}

Keywords: Water quality; Parameters; Anthropogenic; Pollution; Eleyele reservoir

\section{Introduction}

Lakes are socio-economically and bio-aesthetically important aquatic systems [1]. They are reservoir of water comprises of diverse fish food which are essential resources for sustaining development of any nation. Nigeria is among the tropical countries endowed with immense renewable natural resources including freshwater resources. One of these resources is Eleyele reservoir in Southwestern Nigeria. Eleyele reservoir is a modified natural wetland type with area of about $100 \mathrm{~km}^{2}$ including the catchment [2]. The Eleyele reservoir constructed in 1942, constitute a very important part of natural heritage which have widely been utilized by people of Ibadan and environs for decades. It is one of the most important lake systems in Southwest, Nigeria that provide nursery and breeding grounds for a large variety of fish species [3]. The reservoir is also abstracted by the Oyo State Water Corporation at Eleyele Treatment Works for treatment and supply of portable water to Ibadan people [4]. Thus, the reservoir is used primarily as a source of fishery development, domestic water supply and flood control.

Regrettably, Eleyele reservoir is fast becoming degraded due to pollution arising from domestic wastes, industrial effluent, agricultural run-offs and bad fishing practices. According to Ajani and Omitoyin [5], the free style way of disposing agricultural, industrial and domestic effluent into natural water bodies have cause serious contamination of the reservoir. It is currently believed that the Eleyele reservoir is impacted by chemical and pesticides released by agricultural activities, effluents discharged from aquaculture, solid wastes dumped from residential areas and fishing of juvenile fishes by artisanal fishermen. This problem came in the face of population explosion leading to speedy industrialization and urbanization in Ibadan. According to Abe et al. deteriorating habitat quality has become a debatable question for ecologists as these factors are expected to have adverse effects on fishes both physiologically and morphologically.

The quality of water in any ecosystem provides significant information about the available resources for supporting life in that ecosystem. Effluent discharges from industries contribute a serious environmental threat to water quality and aquatic resources, including biodiversity. However, declining water quality due to environmental perturbations threatens the stability of the biotic integrity and therefore hinders the ecosystem services and functions of aquatic ecosystems. Fish growth is directly related to the quality of the water; hence, water quality monitoring can be used as an index to assess the status of aquatic ecosystem in which the fish lives [6]. Water quality assessment generally involves analysis of physico-chemical, biological and microbiological parameters and addresses abiotic and biotic status of the ecosystem [7]

Several documented reports exist on the physic-chemical dynamics in Nigeria. These include the works of Olorode et al. [8] on five different rivers in River State, Hassan et al. [9] on Lower Ogun River, Akindele et al. [10] on Lake Tiga, Idowu et al. [11] on Ado-Ekiti reservoir, Onazeyi [12] on River Ogun, Iloba [13] on Ethiope River, Ogbuagu et al. [14] on Imo River, Ogunfowokan et al. [15] on three reservoirs in Osun State, Essien-Ibok et al. [16] on Mbo river, Bolaji [17] on Eleyele Lake catchment, Ayoola and Ajani [18] on wetland areas in Oyo State, Ibrahim et al. [19] on Kontagora Reservoir, Mustapha [20] on Oyun reservoir, Fafioye et al. [21] on Omi River, Mustapha and Omotosho [22] on Moro Lake, Idowu et al. [23] on Lake Alau, Kolo and Oladimeji [24] on Shiroro Lake, Oniye et al. [25] on Zaria dam. This work was therefore carried out to investigate some selected physical and chemical parameters of Eleyele reservoir and to make deductions on the temporal

*Corresponding author: Olanrewaju AN, Federal College of Freshwater Fisheries Technology, P.M.B 1060, Maiduguri, Nigeria, Tel: 08035794630; E-mail: arogidigbaonline@yahoo.com

Received July 13, 2017; Accepted October 20, 2017; Published October 23, 2017

Citation: Olanrewaju AN, Ajani EK, Kareem OK (2017) Physico-Chemical Status of Eleyele Reservoir, Ibadan, Nigeria. J Aquac Res Development 8: 512. doi: $10.4172 / 2155-9546.1000512$

Copyright: @ 2017 Olanrewaju AN, et al. This is an open-access article distributed under the terms of the Creative Commons Attribution License, which permits unrestricted use, distribution, and reproduction in any medium, provided the original author and source are credited. 


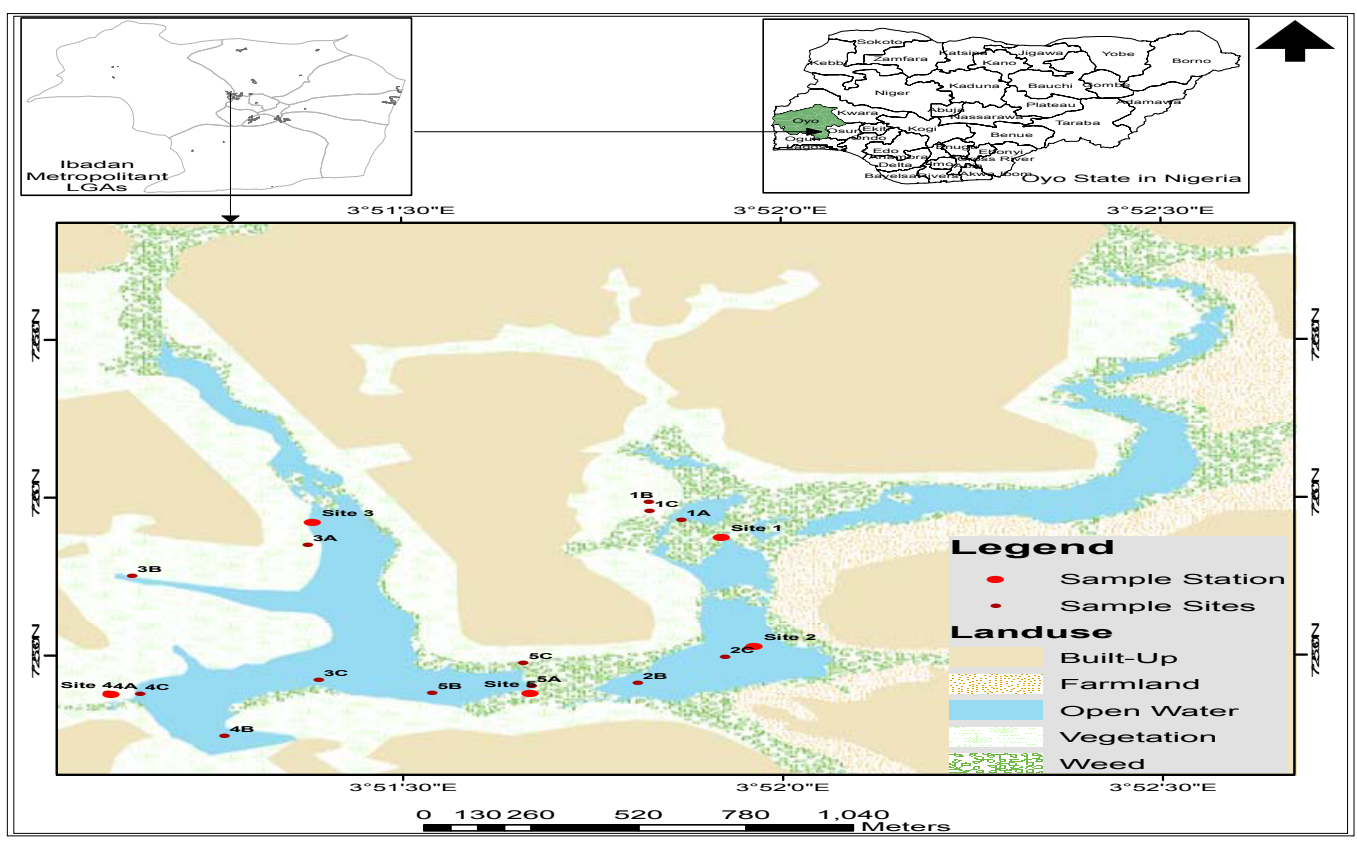

Figure 1: Land use/land cover and sampling distribution in Eleyele reservoir.

and spatial variations in water quality in terms of pollution and productivity.

\section{Materials and Methods}

Eleyele reservoir (Figure 1) is the second largest reservoir in Oyo State, Nigeria, stretching from Latitude $7^{\circ} 25^{\prime} 30^{\prime \prime}-7^{\circ} 26^{\prime} 30^{\prime \prime} \mathrm{N}$ and Longitude $3051^{\prime} 30^{\prime \prime}-3^{\circ} 52^{\prime} 30^{\prime \prime} \mathrm{E}$. The features of the reservoir have been adequately described by Kareem et al. [26] who reported that the reservoir is usually flooded with the water level rising during early period of rainy season. Five sampling stations were chosen within the lake based on hydrological features $[27,28]$. These stations were designated as S1: Apete/Elewure, S2: Agbaje/Babalegba, S3: Oteru/ Oniyere, S4: Arinkinkin/Spillway and S5: Elemu/Ago-Ilaje (Figure 1). The name of each station represents the entry points of rivers and streams into the main Reservoir besides numerous tributaries as well as the exit point. Also, three sampling points were randomly selected in each station. The exact location of each sampling points was determined by using Garmin's GPSMAP eTrex 10 type Sensors.

Water samples were collected at the five stations fortnightly in clean plastic air tight bottles $(250 \mathrm{ml})$ for 24 months (November 2014-October 2016) during early hour of morning (07:00-08:00 hr). Water temperature, $\mathrm{pH}$, transparency and depth were measured insitu. Temperature was measured with a Celcius thermometer of $0.1^{\circ} \mathrm{C}$ readability, $\mathrm{pH}$ by a portable digital meter (Hanna model H1-98107), transparency by Secchi disc and depth with calibrated rope supported with iron rod. In the Wet laboratory of Aquaculture and Fisheries Management, Winkler's method was employed for dissolved oxygen, Intelligent meter (AD. 33915) for conductivity and total dissolved solid, HANNA meter (HI3811) for total alkalinity while chloride, total hardness, calcium, magnesium, sodium, potassium, total dissolved solids, total solids, biochemical oxygen demand, chemical oxygen demand, sulphate, phosphate, nitrate, nitrite and ammonia were analyzed according to APHA [29] and Hach [30]. Air temperature, humidity and rainfall data was collected from the Meteorological unit, Department of Geography, University of Ibadan, Nigeria. Data generated were subjected to both descriptive (means and standard deviations) and inferential statistics (ANOVA) at $\mathrm{p} \leq 0.05$ with the data pooled and presented as seasonal and spatial mean variances. Statistical test was performed using SPSS (version 20.0, SPSS Inc., Chicago, II, USA) for Windows, 2007 while Duncan New multiple Range Test was employed to separate means of parameter with significant difference.

\section{Results}

A summary of the physical and chemical parameters Eleyele

\begin{tabular}{|c|c|c|c|}
\hline \multirow{2}{*}{ Parameter } & \multirow{2}{*}{ Range } & \multirow{2}{*}{ Mean \pm SD } & Optimum range \\
\hline & & & (Boyd in 1998) \\
\hline $\mathrm{DO}\left(\mathrm{mgl}^{-1}\right)$ & $2.18-6.86$ & $4.69 \pm 0.99$ & $5.0-10.0$ \\
\hline $\mathrm{BOD}\left(\mathrm{mgl}^{-1}\right)$ & $1.13-16.80$ & $4.29 \pm 2.23$ & $<10.0$ \\
\hline $\operatorname{COD}\left(\mathrm{mgl}^{-1}\right)$ & $53.4-325.00$ & $130.23 \pm 53.26$ & $<50.0$ \\
\hline Transparency (m) & $0.30-2.00$ & $0.81 \pm 0.35$ & $0.3-0.4$ \\
\hline Temperature $\left({ }^{\circ} \mathrm{C}\right)$ & $22.00-32.20$ & $26.64 \pm 2.36$ & $25.0-32.0$ \\
\hline Conductivity $\left(\mu \mathrm{Scm}^{-1}\right)$ & $0.19-0.37$ & $0.270 \pm 0.21$ & $50-500$ \\
\hline $\mathrm{pH}$ & $5.66-8.46$ & $7.11 \pm 0.53$ & $6.5-8.5$ \\
\hline Nitrate $\left(\mathrm{mgl}^{-1}\right)$ & $1.24-11.50$ & $3.84 \pm 1.95$ & $0.1-3.0$ \\
\hline Nitrite $\left(\mathrm{mgl}^{-1}\right)$ & $0.01-1.25$ & $0.22 \pm 0.13$ & $0.0-0.5$ \\
\hline Ammonia $\left(\mathrm{mgl}^{-1}\right)$ & $0.25-6.81$ & $2.03 \pm 1.15$ & $0.0-1.0$ \\
\hline Phosphate $\left(\mathrm{mgl}^{-1}\right)$ & $0.53-3.63$ & $1.93 \pm 0.62$ & 0.12 \\
\hline Alkalinity $\left(\mathrm{mgl}^{-1}\right)$ & $59.90-152.60$ & $100.42 \pm 14.69$ & $50.0-300.0$ \\
\hline Chloride $\left(\mathrm{mgl}^{-1}\right)$ & $1.53-51.60$ & $10.11 \pm 8.96$ & $31.0-50.0$ \\
\hline Hardness $\left(\mathrm{mgl}^{-1}\right)$ & $11.60-138.00$ & $69.18 \pm 30.94$ & $30.0-180.0$ \\
\hline TDS $\left(\mathrm{mgl}^{-1}\right)$ & $58.00-298.00$ & $158.79 \pm 33.23$ & $30.0-200$ \\
\hline Total solids $\left(\mathrm{mgl}^{-1}\right)$ & $90.00-782.00$ & $358.26 \pm 144.22$ & $<500.0$ \\
\hline Calcium $\left(\mathrm{mgl}^{-1}\right)$ & $2.10-58.50$ & $24.77 \pm 13.39$ & $75.0-200.0$ \\
\hline Magnesium $\left(\mathrm{mgl}^{-1}\right)$ & $0.71-6.47$ & $3.51 \pm 1.31$ & $<150$ \\
\hline Sodium $\left(\mathrm{mgl}^{-1}\right)$ & $0.01-1.86$ & $0.36 \pm 0.25$ & $<500$ \\
\hline Potassium $\left(\mathrm{mgl}^{-1}\right)$ & $0.01-0.91$ & $0.27 \pm 0.21$ & $0.5-10.0$ \\
\hline Sulphate $\left(\mathrm{mgl}^{-1}\right)$ & $6.58-50.10$ & $14.05 \pm 5.54$ & $<400$ \\
\hline Depth (m) & $1.20-11.10$ & $5.17 \pm 1.94$ & - \\
\hline
\end{tabular}

Table 1: Mean ( \pm SD) and ranges of physico-chemical characteristics of Eleyele reservoir. 
Citation: Olanrewaju AN, Ajani EK, Kareem OK (2017) Physico-Chemical Status of Eleyele Reservoir, Ibadan, Nigeria. J Aquac Res Development 8: 512. doi: 10.4172/2155-9546.1000512

Page 3 of 8

\begin{tabular}{|c|c|c|c|c|c|}
\hline Parameters & S1 & S2 & S3 & S4 & S5 \\
\hline $\mathrm{DO}\left(\mathrm{mgL}^{-1}\right)$ & $4.48 \pm 0.71^{\mathrm{ab}}$ & $4.24 \pm 0.84^{a}$ & $4.60 \pm 1.17^{b}$ & $4.78 \pm 0.96^{b}$ & $5.39 \pm 0.82^{c}$ \\
\hline $\mathrm{BOD}\left(\mathrm{mgL}^{-1}\right)$ & $4.26 \pm 2.42^{\mathrm{ab}}$ & $4.57 \pm 3.34^{b}$ & $4.08 \pm 1.74^{\mathrm{ab}}$ & $3.73 \pm 1.20^{\mathrm{a}}$ & $4.80 \pm 1.69^{b}$ \\
\hline $\operatorname{COD}\left(\mathrm{mgL}^{-1}\right)$ & $134.06 \pm 55.53^{b}$ & $132.30 \pm 57.60^{\mathrm{b}}$ & $123.52 \pm 51.78^{a}$ & $128.39 \pm 49.29^{a b}$ & $132.85 \pm 52.48^{b}$ \\
\hline Transparency (m) & $0.79 \pm 0.37^{a}$ & $0.84 \pm 0.34^{a}$ & $0.80 \pm 0.35^{\mathrm{a}}$ & $0.81 \pm 0.36^{a}$ & $0.82 \pm 0.34^{a}$ \\
\hline Temperature $\left({ }^{\circ} \mathrm{C}\right)$ & $26.86 \pm 2.45^{\mathrm{a}}$ & $26.62 \pm 2.57^{a}$ & $26.66 \pm 2.25^{\mathrm{a}}$ & $26.54 \pm 2.38^{a}$ & $26.53 \pm 2.20^{\mathrm{a}}$ \\
\hline Conductivity $\left(\mu \mathrm{Scm}^{-1}\right)$ & $0.285 \pm 0.04^{c}$ & $0.294 \pm 0.04^{c}$ & $0.261 \pm 0.04^{\mathrm{ab}}$ & $0.253 \pm 0.03^{a}$ & $0.266 \pm 0.03^{b}$ \\
\hline $\mathrm{pH}$ & $7.05 \pm 0.47^{a}$ & $7.16 \pm 0.56^{a}$ & $7.14 \pm 0.54^{a}$ & $7.08 \pm 0.55^{\mathrm{a}}$ & $7.14 \pm 0.53^{a}$ \\
\hline Nitrate $\left(\mathrm{mgL}^{-1}\right)$ & $3.98 \pm 2.07^{\mathrm{ab}}$ & $4.44 \pm 2.71^{\mathrm{b}}$ & $3.66 \pm 1.85^{\mathrm{a}}$ & $3.53 \pm 1.34^{\mathrm{a}}$ & $3.64 \pm 1.36^{a}$ \\
\hline Nitrite $\left(\mathrm{mgL}^{-1}\right)$ & $0.23 \pm 0.17^{a}$ & $0.23 \pm 0.19^{a}$ & $0.22 \pm 0.15^{\mathrm{a}}$ & $0.24 \pm 0.21^{\mathrm{a}}$ & $0.20 \pm 0.13^{a}$ \\
\hline Ammonia $\left(\mathrm{mgL}^{-1}\right)$ & $2.42 \pm 1.46^{c}$ & $2.56 \pm 1.63^{c}$ & $1.92 \pm 0.70^{b}$ & $1.75 \pm 0.60^{\mathrm{ab}}$ & $1.52 \pm 0.50^{\mathrm{a}}$ \\
\hline Phosphate $\left(\mathrm{mgL}^{-1}\right)$ & $1.90 \pm 0.47^{a}$ & $2.00 \pm 0.69^{a}$ & $1.91 \pm 0.61^{a}$ & $1.94 \pm 0.66^{a}$ & $1.93 \pm 0.65^{\mathrm{a}}$ \\
\hline Alkalinity $\left(\mathrm{mgL}^{-1}\right)$ & $100.16 \pm 18.97^{\mathrm{ab}}$ & $103.63 \pm 14.87^{b}$ & $100.09 \pm 14.21^{\mathrm{ab}}$ & $96.25 \pm 11.41^{\mathrm{a}}$ & $101.94 \pm 12.16^{b}$ \\
\hline Hardness $\left(\mathrm{mgL}^{-1}\right)$ & $73.52 \pm 30.11^{b}$ & $69.88 \pm 33.08^{\mathrm{ab}}$ & $71.23 \pm 32.08^{\mathrm{ab}}$ & $70.89 \pm 29.53^{\mathrm{ab}}$ & $60.35 \pm 28.88^{a}$ \\
\hline TDS $\left(\mathrm{mgL}^{-1}\right)$ & $163.46 \pm 30.84^{b c}$ & $168.64 \pm 39.47^{b}$ & $160.17 \pm 30.95^{\mathrm{bc}}$ & $148.00 \pm 27.10^{a}$ & $153.71 \pm 33.39^{a b}$ \\
\hline Total solid $\left(\mathrm{mgL}^{-1}\right)$ & $341.17 \pm 114.37^{a}$ & $343.75 \pm 117.65^{\mathrm{a}}$ & $392.75 \pm 161.05^{\mathrm{a}}$ & $360.32 \pm 171.56^{a}$ & $353.33 \pm 145.39^{a}$ \\
\hline Calcium $\left(\mathrm{mgL}^{-1}\right)$ & $26.78 \pm 14.36^{a}$ & $24.45 \pm 14.16^{a}$ & $25.00 \pm 12.23^{a}$ & $24.48 \pm 13.18^{a}$ & $23.12 \pm 13.01^{a}$ \\
\hline Magnesium $\mathrm{mgL}^{-1}$ ) & $4.09 \pm 1.27^{d}$ & $3.74 \pm 1.20^{\mathrm{cd}}$ & $3.23 \pm 1.25^{\mathrm{ab}}$ & $3.46 \pm 1.40^{\mathrm{bc}}$ & $3.01 \pm 1.21^{\mathrm{a}}$ \\
\hline Sulphate $\left(\mathrm{mgL}^{-1}\right)$ & $14.05 \pm 4.65^{\mathrm{a}}$ & $14.37 \pm 5.12^{\mathrm{a}}$ & $14.61 \pm 5.44^{a}$ & $13.09 \pm 3.97^{a}$ & $14.13 \pm 7.79^{a}$ \\
\hline Chloride $\left(\mathrm{mgl}^{-1}\right)$ & $13.12 \pm 11.05^{b}$ & $14.19 \pm 13.66^{b}$ & $3.11 \pm 1.06^{a}$ & $15.76 \pm 14.13^{b}$ & $4.36 \pm 2.00^{\mathrm{a}}$ \\
\hline Sodium $\left(\mathrm{mgl}^{-1}\right)$ & $0.42 \pm 0.31^{a}$ & $0.39 \pm 0.35^{a}$ & $0.28 \pm 0.22^{\mathrm{a}}$ & $0.33 \pm 0.25^{a}$ & $0.37 \pm 0.33^{a}$ \\
\hline Potassium $\left(\mathrm{mgl}^{-1}\right)$ & $0.27 \pm 0.21^{a}$ & $0.28 \pm 0.23^{a}$ & $0.27 \pm 0.22^{\mathrm{a}}$ & $0.26 \pm 0.20^{a}$ & $0.24 \pm 0.17^{a}$ \\
\hline Depth $(\mathrm{m})$ & $4.48 \pm 1.88^{a}$ & $4.61 \pm 1.67^{b}$ & $5.35 \pm 1.73^{b}$ & $6.53 \pm 1.86^{c}$ & $4.89 \pm 1.84^{\mathrm{ab}}$ \\
\hline
\end{tabular}

Table 2: Spatial variation in physico-chemical parameters of Eleyele reservoir.

Reservoir is presented in Table 1 , including the mean \pm standard deviation, minimum and maximum values. Results obtained from the study showed that DO 2.18-6.86 mgl- $\left(4.69 \pm 0.99 \mathrm{mgl}^{-1}\right)$, chloride 1.53-51.60 mgl- ${ }^{-1}\left(10.11 \pm 8.96 \mathrm{mgl}^{-1}\right)$; calcium 2.10-58.50 $\mathrm{mgl}^{-1}(24.77 \pm$ $\left.13.39 \mathrm{mgl}^{-1}\right)$; COD 53.40-325.00 mgl- ${ }^{-1}\left(130.23 \pm 53.26 \mathrm{mgl}^{-1}\right)$, phosphate 0.53-3.63 mgl${ }^{-1}\left(1.93 \pm 0.62 \mathrm{mgl}^{-1}\right)$; ammonia $0.25-6.81 \mathrm{mgl}^{-1}(2.03 \pm$ $\left.1.15 \mathrm{mgl}^{-1}\right)$, and transparency $0.30-2.00 \mathrm{~m}(0.81 \pm 0.35 \mathrm{~m})$ were below the recommended standard limit.

The comparison of different parameters investigated with standard optimum range shows some factors like BOD, surface temperature, conductivity, $\mathrm{pH}$, nitrite, alkalinity, total hardness, total dissolved solids, total solid, magnesium, sodium and sulphate were within optimum standard range while others were either below (DO, chloride, calcium and potassium) or above (COD, water transparency, nitrate, ammonia and phosphate) permissible level.

The mean $( \pm S D)$ spatial values of physic-chemical factors measured during the study are shown in Table 2. Analysis of variance (ANOVA), revealed that with the exception of transparency, temperature, $\mathrm{pH}$, nitrite, phosphate, total solids, calcium, sodium, potassium and sulphate, that showed non-significant variations $(p>0.05)$, in the five sampling stations, all other parameters showed marked variations $(\mathrm{p}<0.05)$. The mean dissolved oxygen content of the Reservoir was 4.69 $\pm 0.9 \mathrm{mg} / \mathrm{l}$ and it varies from $4.24 \pm 0.84 \mathrm{mg} / \mathrm{l}$ in S2 to $5.39 \pm 0.82 \mathrm{mgl}^{-1}$ in S5. BOD values across the sampling stations fluctuated between 3.73 $\pm 1.20 \mathrm{mgl}^{-1}$ (Station 4) and $4.80 \pm 1.69 \mathrm{mgl}^{-1}$ (S5), with a mean of 4.29 $\pm 2.23 \mathrm{mgl}^{-1}$. S1 recorded the highest mean COD $(134.06 \pm 55.53 \mathrm{mgl}$ $\left.{ }^{1}\right)$ while the lowest value of $123.52 \pm 51.78 \mathrm{mgl}^{-1}$ was observed in $\mathrm{S} 3$. The transparency was showed very narrow changes in all stations and varied between $0.79 \pm 0.37 \mathrm{~m}$ and $0.84 \pm 0.34 \mathrm{~m}$. The maximum value was recorded in S1 and the minimum in S2, while the overall mean transparency recorded was $0.81 \pm 0.35 \mathrm{~m}$.

Water temperature had its peak value in $\mathrm{S} 1\left(26.86 \pm 2.45^{\circ} \mathrm{C}\right)$ and least value in $\mathrm{S} 5\left(26.53 \pm 2.20^{\circ} \mathrm{C}\right)$. The general mean water temperature in the Reservoir was $26.64 \pm 2.36^{\circ} \mathrm{C}$. Values for conductivity ranged from $0.253 \pm 0.03 \mu \mathrm{Scm}^{-1}$ (S4) to $0.285 \pm 0.04 \mu \mathrm{Scm}^{-1}$ (S1) with the overall mean value of $0.275 \pm 0.04 \mu \mathrm{Scm}^{-1}$. The mean $\mathrm{pH}$ value across stations was $7.11 \pm 0.53$ with the highest mean pH $(7.16 \pm 0.56)$ obtained in S2. Evident variations were observed in Nitrate with S2 had the highest value of $4.44 \pm 2.71 \mathrm{mgl}^{-1}$ and least $\left(3.53 \pm 1.34 \mathrm{mgl}^{-1}\right)$ found in S4. The mean nitrite value ranged from $0.20 \pm 0.13 \mathrm{mgl}^{-1}$ in S5 to $0.24 \pm$ 0.21 in S4 showing little changes. S1 and S2 showed significant highest ammonia concentration of $2.42 \pm 1.46$ and $2.56 \pm 1.63$, respectively. Also, S2 recorded the highest mean value for phosphate $(2.00 \pm 0.69$ $\left.\mathrm{mgl}^{-1}\right)$ and alkalinity $\left(103.63 \pm 14.87 \mathrm{mgl}^{-1}\right)$ while maximum value in chloride was realized in S4 $\left(15.76 \pm 14.13 \mathrm{mgl}^{-1}\right)$.

Total Dissolved Solids (TDS) concentrations was highest in S2 $\left(168.64 \pm 39.47 \mathrm{mgl}^{-1}\right)$ and lowest in S4 $\left(148.00 \pm 27.10 \mathrm{mgl}^{-1}\right)$, with overall mean of $158.79 \pm 33.23 \mathrm{mgl}^{-1}$. Mean total hardness ranged from $60.35 \pm 28.88$ to $73.52 \pm 30.11$. The highest total hardness was recorded in S1 while the least was recorded in S5. The values of total solids varied between $341.17 \pm 114.37 \mathrm{mgl}^{-1}$ to $392.75 \pm 161.05 \mathrm{mgl}^{-1}$, with maximum value in $\mathrm{S} 3$ and minimum in $\mathrm{S} 1$. Calcium concentration ranged between $23.12 \pm 13.01 \mathrm{mgl}^{-1}$ to $26.78 \pm 14.36 \mathrm{mgl}^{-1}$ with lowest in $\mathrm{S} 5$ and highest in S1, respectively. For magnesium and sodium, S1 showed highest value of $4.09 \pm 1.27 \mathrm{mgl}^{-1}$ and $0.42 \pm 0.31 \mathrm{mgl}^{-1}$, respectively while highest potassium value was observed in S2. The average value of total hardness during the study was $69.18 \pm 30.94 \mathrm{mgl}^{-1}$ with lowest value of $60.35 \pm 28.88 \mathrm{mgl}^{-1}$ in S5 and highest value of $73.52 \pm 30.11 \mathrm{mgl}^{-1}$ in S1. The highest sulphate value of $14.61 \pm 5.44 \mathrm{mgl}^{-1}$ was observed in $\mathrm{S} 3$ and lowest value of $13.09 \pm 3.97 \mathrm{mgl}^{-1}$ was observed in S4. Mean depth of visibility was $5.17 \pm 1.94 \mathrm{~m}$ with maximum of $6.53 \pm 1.86 \mathrm{~m}$ in $\mathrm{S} 4$ and minimum of $4.48 \pm 1.88 \mathrm{~m}$ in $\mathrm{S} 1$.

The seasonal variation patterns in the physico-chemical water quality of Eleyele reservoir are provided in Table 3. Results showed that mean DO $\left(\mathrm{mgl}^{-1}\right)$ values, COD $\left(\mathrm{mgl}^{-1}\right)$, water transparency $(\mathrm{m})$, surface temperature $\left({ }^{\circ} \mathrm{C}\right)$, conductivity $\left(\mu \mathrm{Scm}^{-1}\right)$, nitrate $\left(\mathrm{mgl}^{-1}\right)$, ammonia $\left(\mathrm{mgl}^{-1}\right)$, phosphate $\left(\mathrm{mgl}^{-1}\right)$, chloride $\left(\mathrm{mgl}^{-1}\right)$, total hardness $\left(\mathrm{mgl}^{-1}\right)$, TDS $\left(\mathrm{mgl}^{-1}\right)$ TS $\left(\mathrm{mgl}^{-1}\right)$, calcium $\left(\mathrm{mgl}^{-1}\right)$, magnesium $\left(\mathrm{mgl}^{-1}\right)$, sodium $\left(\mathrm{mgl}^{-1}\right)$, potassium $\left(\mathrm{mgl}^{-1}\right)$, sulphate $\left(\mathrm{mgl}^{-1}\right)$, and depth $(\mathrm{m})$ vary significantly 


\begin{tabular}{|c|c|c|c|}
\hline Parameters & Wet season & Dry season & P-value \\
\hline DO $\left(\mathrm{mgl}^{-1}\right)$ & $4.85 \pm 0.97$ & $4.48 \pm 0.98$ & $0.00^{*}$ \\
\hline BOD $\left(\mathrm{mgl}^{-1}\right)$ & $4.82 \pm 2.66$ & $3.54 \pm 1.03$ & 0.00 \\
\hline COD $\left(\mathrm{mgl}^{-1}\right)$ & $157.27 \pm 53.42$ & $93.26 \pm 18.88$ & $0.00^{*}$ \\
\hline Transparency $(\mathrm{m})$ & $0.60 \pm 0.18$ & $1.11 \pm 0.32$ & $0.00^{*}$ \\
\hline Temperature $\left({ }^{\circ} \mathrm{C}\right)$ & $25.53 \pm 1.74$ & $28.20 \pm 2.34$ & $0.00^{*}$ \\
\hline Conductivity $\left(\mu \mathrm{scm}^{-1}\right)$ & $0.276 \pm 0.04$ & $0.265 \pm 0.04$ & $0.01^{*}$ \\
\hline pH & $7.07 \pm 0.53$ & $7.17 \pm 0.52$ & 0.06 \\
\hline Nitrate $\left(\mathrm{mgl}^{-1}\right)$ & $4.67 \pm 2.12$ & $2.75 \pm 0.63$ & $0.00^{*}$ \\
\hline Nitrite $\left(\mathrm{mgl}^{-1}\right)$ & $0.23 \pm 0.16$ & $0.21 \pm 0.19$ & 0.32 \\
\hline Ammonia $\left(\mathrm{mgl}^{-1}\right)$ & $2.33 \pm 1.34$ & $1.61 \pm 0.61$ & $0.00^{*}$ \\
\hline Phosphate $\left(\mathrm{mgl}^{-1}\right)$ & $2.10 \pm 0.61$ & $1.71 \pm 0.55$ & $0.00^{*}$ \\
\hline Total alkalinity $\left(\mathrm{mgl}^{-1}\right)$ & $100.91 \pm 16.14$ & $99.72 \pm 12.41$ & 0.45 \\
\hline Chloride $\left(\mathrm{mgl}^{-1}\right)$ & $12.64 \pm 10.22$ & $6.56 \pm 5.39$ & $0.00^{*}$ \\
\hline Total Hardness $\left(\mathrm{mgl}^{-1}\right)$ & $72.65 \pm 32.51$ & $64.31 \pm 28.00$ & $0.01^{*}$ \\
\hline TDS $\left(\mathrm{mgl}^{-1}\right)$ & $169.82 \pm 31.19$ & $143.13 \pm 29.50$ & $0.00^{*}$ \\
\hline Total solids $\left(\mathrm{mgl}^{-1}\right)$ & $421.00 \pm 133.64$ & $270.43 \pm 108.41$ & $0.00^{*}$ \\
\hline Calcium $\left(\mathrm{mgl}^{-1}\right)$ & $18.99 \pm 13.89$ & $32.85 \pm 6.97$ & $0.00^{*}$ \\
\hline Magnesium $\left(\mathrm{mgl}^{-1}\right)$ & $2.99 \pm 1.28$ & $4.22 \pm 0.98$ & $0.00^{*}$ \\
\hline Sodium $\left(\mathrm{mgl}^{-1}\right)$ & $0.21 \pm 0.18$ & $0.56 \pm 0.46$ & $0.00^{*}$ \\
\hline Potassium $\left(\mathrm{mgl}^{-1}\right)$ & $0.32 \pm 0.17$ & $0.18 \pm 0.14$ & $0.00^{*}$ \\
\hline Sulphate $\left(\mathrm{mgl}^{-1}\right)$ & $11.97 \pm 2.93$ & $16.96 \pm 6.87$ & $0.00^{*}$ \\
\hline Depth $\left(\mathrm{m}^{*}\right)$ & $5.74 \pm 1.78$ & $4.37 \pm 1.86$ & $0.00^{*}$ \\
\hline Table $3 . \mathrm{Seas}^{*}$ & & & \\
\hline
\end{tabular}

Table 3: Seasonal physico-chemical parameters of Eleyele reservoir.

$(\mathrm{P}<0.05)$ between seasons while BOD $\left(\mathrm{mgl}^{-1}\right), \mathrm{pH}$ values, nitrite $\left(\mathrm{mgl}^{-1}\right)$ and alkalinity $\left(\mathrm{mgl}^{-1}\right)$ were not significantly different between seasons $(\mathrm{P}>0.05)$.

The mean dry season values of transparency $(1.11 \pm 0.32 \mathrm{~m}), \mathrm{pH}$ $(7.17 \pm 0.52)$, surface temperature $\left(28.20 \pm 2.34^{\circ} \mathrm{C}\right)$, calcium $(32.85 \pm$ $\left.6.97 \mathrm{mgl}^{-1}\right)$, magnesium $\left(4.22 \pm 0.98 \mathrm{mgl}^{-1}\right)$, sodium $\left(0.56 \pm 0.46 \mathrm{mgl}^{-1}\right)$ and sulphate $\left(16.96 \pm 6.87 \mathrm{mgl}^{-1}\right)$ were higher than those of wet seasons. However, dissolved oxygen $\left(4.85 \pm 0.97 \mathrm{mgl}^{-1}\right)$, BOD $\left(4.82 \pm 2.66 \mathrm{mgl}^{-}\right.$ $\left.{ }^{1}\right)$, COD $\left(157.27 \pm 53.42 \mathrm{mgl}^{-1}\right)$, conductivity $\left(0.276 \pm 0.04 \mu \mathrm{Scm}^{-1}\right)$, nitrate $\left(4.67 \pm 2.12 \mathrm{mgl}^{-1}\right)$, nitrite $\left(0.23 \pm 0.16 \mathrm{mgl}^{-1}\right)$, ammonia $(2.33$ $\left.\pm 1.34 \mathrm{mgl}^{-1}\right)$, phosphate $\left(2.10 \pm 0.61 \mathrm{mgl}^{-1}\right)$, alkalinity $(100.91 \pm 16.14$ $\left.\mathrm{mgl}^{-1}\right)$, chloride $\left(12.64 \pm 10.22 \mathrm{mgl}^{-1}\right)$, total hardness $\left(72.65 \pm 32.51 \mathrm{mgl}^{-}\right.$ $\left.{ }^{1}\right)$, total dissolved solids $\left(169.82 \pm 31.19 \mathrm{mgl}^{-1}\right)$, total solids $(421.00 \pm$ $\left.133.64 \mathrm{mgl}^{-1}\right)$, potassium $\left(0.32 \pm 0.17 \mathrm{mgl}^{-1}\right)$ and water depth $(5.74 \pm$ $1.78 \mathrm{~m}$ ) were higher in the wet season than the dry season.

Results of the correlation coefficient matrix between the various physico-chemical parameters studied are presented in Table 4 . The dissolved oxygen had positive significant $(p<0.01)$ relationship with potassium $(\mathrm{r}=0.259)$, total dissolved solids $(\mathrm{r}=0.278)$, total solids $(\mathrm{r}=0.362)$ and phosphate $(\mathrm{r}=0.422)$. It however showed negative significant correlation with $\mathrm{pH}(\mathrm{r}=-0.172)$, chloride $(\mathrm{r}=-0.386)$, calcium $(\mathrm{r}=-0.253)$, magnesium $(\mathrm{r}=-0.436)$, sodium $(\mathrm{r}=-0.293)$, ammonia $(\mathrm{r}=-$ $0.297)$ and transparency $(\mathrm{r}=-0.140)$. Total alkalinity revealed negative significant association $(\mathrm{p}<0.01)$ with $\mathrm{pH}(\mathrm{r}=-0.241)$, and very weak correlation with dissolved oxygen $(\mathrm{r}=0.064)$. There exists positive significant connection between chloride and total alkalinity $(\mathrm{r}=0.120$; $\mathrm{p}<0.05)$ while a weak relationship occurred between chloride and $\mathrm{pH}$ $(\mathrm{r}=0.054)$.

Total hardness showed a negative significance with $\mathrm{pH}(\mathrm{r}=0.402$; $\mathrm{p}<0.01)$, positive significance with total alkalinity $(\mathrm{r}=0.188 ; \mathrm{p}<0.01)$ and significant positive correlation with chloride $(\mathrm{r}=0.186 ; \mathrm{p}<0.01)$. Calcium $(\mathrm{r}=0.071)$ and magnesium $(\mathrm{r}=0.088)$ are weakly associated with total alkalinity, however, they have positive significance $(\mathrm{p}<0.01)$ with chloride. Sodium showed positive significance at $\mathrm{p}<0.01$ with $\mathrm{pH}$ $(\mathrm{r}=0.290)$, calcium $(\mathrm{r}=0.141)$ and magnesium $(\mathrm{r}=0.322)$. It however indicated negative significance with alkalinity $(\mathrm{r}=-0.185 ; \mathrm{p}<0.01)$ ), chloride $(\mathrm{r}=-0.056)$ and total hardness $(\mathrm{r}=-0.437)$. A strong significant positive correlation $(\mathrm{p}<0.01)$ occurred between potassium and total hardness $(\mathrm{r}=0.520)$, while a significant positive correlation $(\mathrm{p}<0.01)$ occurred between TDS and potassium $(\mathrm{r}=0.363)$ as well as TS and potassium $(r=0.334)$. Also, there is strong and significant correlation at $\mathrm{p}<0.01$ between TS and TDS ( $\mathrm{r}=0.538$ ). There exists positive significant relationship at $\mathrm{p}<0.01$ between BOD and total hardness ( $\mathrm{r}=0.192)$, TDS $(\mathrm{r}=0.328)$ and TS $(\mathrm{r}=0.340)$ but showed significant negative correlation with $\mathrm{pH}(\mathrm{r}=-0.344)$ and sodium $(\mathrm{r}=-0.296)$.

A positive and strong correlation was observed between COD and chloride $(0.518, \mathrm{P}<0.01)$, whereas an inverse correlation was observed with sodium $(-218, \mathrm{P}<0.01)$. Phosphate was inversely strongly correlated with calcium $(-0.500, \mathrm{P}<0.01)$, magnesium $(-0.537, \mathrm{P}<0.01)$ and sodium $(-0.497, \mathrm{P}<0.01)$, but positively associated $(\mathrm{p}<0.01)$ with potassium $(\mathrm{r}=0.228)$, TDS $(\mathrm{r}=0.436)$, TS $(\mathrm{r}=0.462)$ and BOD $(\mathrm{r}=0.298)$. Temperature is positively correlated $(\mathrm{p}<0.01)$ with total hardness $(\mathrm{r}=0.214)$, calcium $(\mathrm{r}=0.257)$, magnesium $(\mathrm{r}=0.142)$, potassium $(r=0.183)$, TDS $(r=0.156)$ and sulphate $(r=0.420)$ while it negatively correlated with the $\mathrm{pH}(\mathrm{r}=-0.207)$, total alkalinity $(\mathrm{r}=-0.129)$, chloride $(\mathrm{r}=-0.371), \mathrm{BOD}(\mathrm{r}=-0.123), \mathrm{COD}(\mathrm{r}=-0.388)$, nitrate $(\mathrm{r}=-0.129)$, nitrite $(r=-0.374)$ and ammonia $(r=-0.470)$. The electrical conductivity was only strongly significantly associated with potassium $(r=0.502)$, total hardness $(\mathrm{r}=0.481)$ and TDS $(\mathrm{r}=0.435)$ and weakly correlated with phosphate () and sulphate $(\mathrm{r}=0.155)$. Also, the depth was correlated positively and significantly $(\mathrm{P}<0.01)$ with chloride $(\mathrm{r}=0.200)$, TS $(\mathrm{r}=0.132)$, COD $(\mathrm{r}=0.239)$, nitrate $(\mathrm{r}=0.116)$ and ammonia $(\mathrm{r}=0.132)$. A positive relationship exists between transparency and temperature $(\mathrm{r}=0.527)$, sulphate $(\mathrm{r}=0.349)$, sodium $(\mathrm{r}=0.278)$, magnesium $(\mathrm{r}=0.245)$ and calcium $(\mathrm{r}=0.241)$.

\section{Discussion}

The proper balance of physical, chemical, and biological properties of water in ponds, lakes and reservoirs is an essential ingredient for successful production of fish and other aquatic resources [22]. However, only few (BOD, temperature, conductivity, total alkalinity, total hardness and ions) among tested parameters in Eleyele Reservoir fell within optimum recommended range for growth and survival [3133]. Further, the spatio-temporal dynamics of the trophic lake is crucial in defining its water quality as well as biodiversity. In the present study, spatial variations among the investigated parameters were mostly statistically significant $(\mathrm{p}<0.05)$ except for transparency, temperature, $\mathrm{pH}$, nitrite, phosphate, total solids, calcium, sodium, potassium and sulphate. According to Atobatele and Ugwumba [34] and Ayoade et al. [35], these marked spatial variations may be related to patterns of water use, temperature and rainfall influx. In contrast, only $\mathrm{pH}, \mathrm{BOD}$, nitrite and total alkalinity showed non-significant $(\mathrm{p}>0.05)$ temporal vicissitudes, and this seasonal vagary pattern is common for most tropical inland ecosystems as a result of allochthonous run-off into river basins during the rainy season [34,36-38].

The dissolved oxygen and BOD levels had the spatial mean values of $4.69 \pm 0.99 \mathrm{mgl}^{-1}$ and $4.29 \pm 2.23 \mathrm{mgl}^{-1}$ respectively in the entire reservoir. These findings were consistent with the results obtained by Ovie et al. [39] in Omi dam, Bolaji [17] in Eleyele Lake, Ibrahim et al. [19] in Kontagora reservoir, and Mustapha and Omotosho [22] in Moro Lake. However, this result implied that dissolved oxygen which is an important factor for aquatic life and the chemical characteristics of the environment was not completely satisfactory for aquatic life in Eleyele reservoir. This viewpoint is corroborated by many authors including Egemen [40], WHO [31] and Boyd [32], who established 


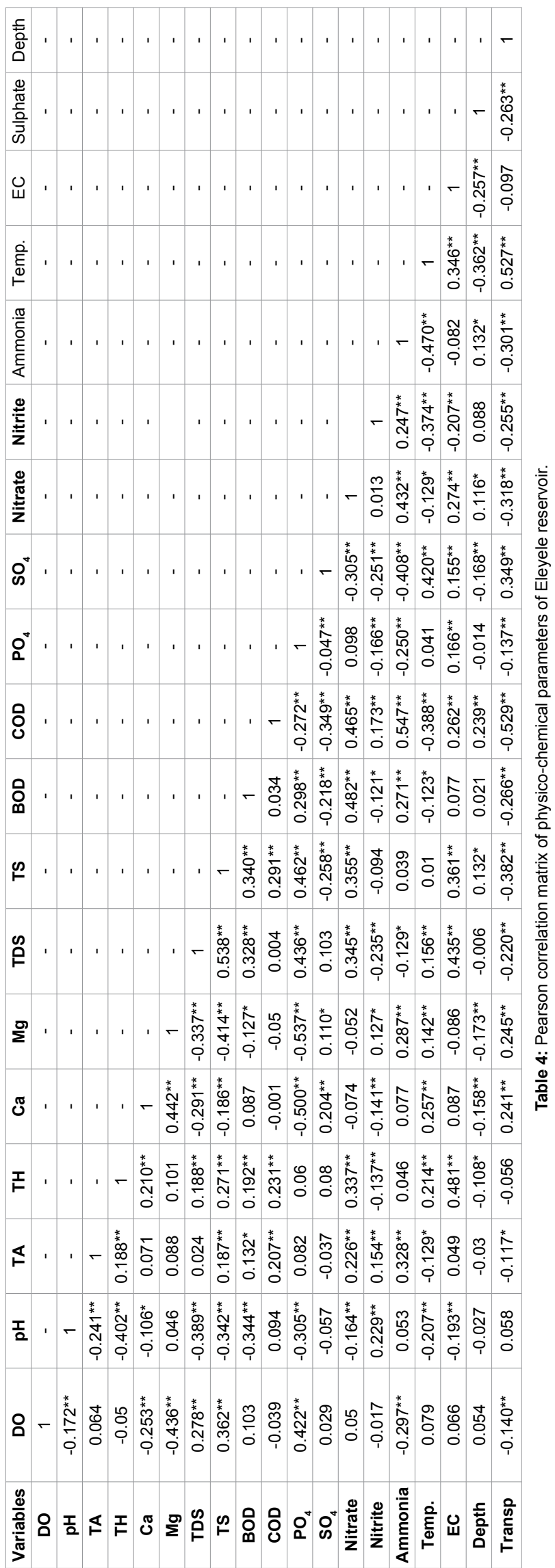


that the minimum dissolved oxygen should not be less than $5 \mathrm{mgl}^{-1}$ for aquatic life in inland ecosystems. Dissolved oxygen and BOD values were significantly higher in Igunle Ero/Ago Ilaje as compared to other Stations. This higher dissolved oxygen in Igunle Ero/Ago Ilaje could be attributed to its transitional zone status between riverine and lentic ecosystem sections of the reservoir, its rich phytoplankton density and strong wind diffusion [36]. In addition, intense activities including fish landing operations and boat traffic in the area could be a supporting factor. Moreover, the concentrations of DO and BOD were significantly higher during wet season as compared to dry season. This observation agreed with the findings of Adjarho et al. [41], Anago et al. [42] Ibrahim [43] and Mustapha [36] in Wasai reservoir (Jakara dam), Awba Reservoir, Oyun Reservoir, and Ona River respectively.

Nitrite content did not show remarkable spatial fluctuation whereas, the results of nitrate and ammonia revealed spatial variation in its content. These variations in nitrate and ammonia concentration throughout the year may be due to microbial utilization as well as varying agricultural inflows. This phenomenon is also reported by Okbah and El-gohary [44] for evaluation of physic-chemical characteristics of Lake Edku, Egypt. The mean nitrate, nitrite and ammonia values recorded for the entire lake fell outside optimum recommended range $[31,32]$, but coincided with the findings of Ovie et al. [39] in Omi dam, Nigeria. Also, higher nitrate, nitrite and ammonia values were observed during wet agreed with the finding of Ayoola and Ajani [18] on wetland areas of Oyo State, Nigeria. The mean temperature and $\mathrm{pH}$ recorded during the study were optimal for normal growth and survival of aquatic organisms [32]. Though, the $\mathrm{pH}$ range (5.66-8.46) which are slightly acidic to mildly alkaline fell below the lower limit defined by standard guidelines of 6.5-8.5 [31]. These results compared well with other similar man-made reservoirs as reported by Idowu et al. [11] in AdoEkiti Reservoir, Akindele and Adeniyi [10] in Opa Reservoir, Anago et al. [42] in Awba Reservoir, Idowu and Ugwumba, [45] in Eleyele Lake, all in Southwestern Nigeria. Surface temperature was significantly high during the dry season and low during the rains. The low temperature observed during the rains could be due to high humidity and moderate or less sunlight in this period of the year. Similar observations have been reported in Ado-Ekiti Reservoir [11], Oyun Reservoir [36], Ero Reservoir [37], Egbe Lake [46], Oyan and Asejire Lakes [35].

The transparency and phosphate revealed non-significant differences in all the stations, although, Agbaje/Babalegba showed the highest spatial values. However, the range and means of these two parameters could be considered as being outrageous when compared with the standard limit recommended for aquatic life growth and survival [32]. In support of this view, Murdoch et al. [47] reported that high levels of both phosphates and nitrates can lead to eutrophication, which increases algal growth and ultimately reduces dissolved oxygen in the water. Phosphate in this study is remarkably higher $(1.93 \pm 0.62$ $\mathrm{mgl}^{-1}$ ) than $0.2-0.5 \mathrm{mgl}^{-1}$ in Moro Lake [22] and $0.49 \pm 0.51 \mathrm{mgl}^{-1}$ in Opa Reservoir [10]. Phosphate and organic matter were also markedly higher in the rainy season than in the dry season. The result agrees with the findings of Onozeyi [12] who work on assessment of some physicchemical parameters of River Ogun. Also, Akindele and Adeniyi [10] asserted that this seasonal pattern can easily be linked to allochthonous inputs from the nearby terrestrial surfaces in the rainy season, thereby increasing their concentrations. The spatial mean value of transparency $(0.81 \pm 0.35 \mathrm{~m})$ show good correspondence with $0.99 \pm 0.26 \mathrm{~m}$ reported by Idowu et al. [11] for Ado-Ekiti Reservoir. Meanwhile, transparency progressively decreased with time with higher value obtained in the dry season $(1.11 \pm 0.32 \mathrm{~m})$. This higher dry season secchi-disc transparency mean value could be due to absence of floodwater, surface run-offs and settling effect of suspended materials that followed the cessation of rainfall. Similar observation was made by Onozeyi [12] in River Ogun, Mustapha, [36] in Oyun lake, Ibrahim et al. [19] in Kontagora Reservoir, Oso and Fagbuaro [37] in Ero Reservoir, Fapohunda and Godstate [46] in Egbe Lake, Ayoade et al. [35] in Asejire and Oyan lakes, Idowu and Ugwumba [45] in Eleyele Reservoir.

The mean TS $\left(358.26 \pm 144.22 \mathrm{mgl}^{-1}\right)$ and TDS $(158.79 \pm 33.23$ $\left.\mathrm{mgl}^{-1}\right)$ in this study was comparably higher than the reported mean values in different lakes [10,36,42]. According to Rain and Thatcher, the quantity of TDS was proportional to the degree of pollution. The TDS were recorded more $\left(168.82 \pm 31.19 \mathrm{mgl}^{-1}\right)$ during wet season and this is because of the addition of solids from ran off water as supported by Kalwale and Savale [48] and Mustapha [36]. Mustapha [36] and Araoye [49] also observed higher TDS concentration during wet season in Asa and Oyun reservoirs, respectively. Water alkalinity and hardness are primarily a function of the geology of the area where the surface water is located and the dissolution of carbon dioxide $\left(\mathrm{CO}_{2}\right)$ from the atmosphere [50]. Alkalinity, $\mathrm{pH}$ and hardness affect the toxicity of many substances in the water. In the present study, the total alkalinity and hardness value recorded compared favourably with the trend obtained in Çamligoze Dam Lake [51] and Kangsabati reservoir [52] and was within the optimum value [32]. There is marked variation in observed spatial alkalinity and hardness, which could be attributed to high influx of floodwater which contains suspended and dissolved materials. Total hardness was highest in wet season and conforms to the findings of Bera et al. [52] on Kangsabati reservoir, Onozeyi [12] on River Ogun, Mustapha and Omotosho [22] on Moro Lake, and Garg [53] on River Mandakini. On the contrary, Hujare [54] reported high total hardness concentration during summer than rainy season and winter season.

The ionic composition of the water in Eleyele Reservoir was dominated by calcium $\left(24.77 \pm 13.39 \mathrm{mgl}^{-1}\right)$ followed by magnesium $\left(3.51 \pm 1.31 \mathrm{mgl}^{-1}\right)$. This phenomenon has also been reported by Golterman and Kouwe [55] as standard for freshwater. In a similar vein, major ions such as $\mathrm{Ca}^{2+}, \mathrm{Na}^{+}, \mathrm{K}^{+}$and $\mathrm{SO}_{4}^{2+}$ was found relatively consistent in all sampling stations, however, little but significant variation in $\mathrm{Mg}^{2+}$ were detected between the stations. Whereas all the major ions $\left(\mathrm{Ca}^{2+}, \mathrm{Na}^{+}, \mathrm{Mg}^{2}\right.$ and $\left.\mathrm{SO}_{4}^{2+}{ }_{-}\right)$except $\mathrm{K}^{+}$were significantly higher in the dry season than in the wet season. Akindele and Adeniyi [10] and Mustapha [36] reported similar observations in Oyun and Opa Lakes respectively. The high content of chloride in the aquatic systems is responsible for a large amount of organic matter which in turn causes eutrophication [56]. Chloride was found optimum during the study ranged from 1.53 to $51.60 \mathrm{mgl}^{-1}$ with a mean value of 10.11 $\pm 8.96 \mathrm{mgl}^{-1}$ [32]. The chloride is higher in the wet season and lower in the dry season, when the dam had low water level. This could be due to high influx of flood water with its attendant concentration of suspended solids. Patra et al. [57], recorded similar result for Karala River.

Conductivity range for the entire reservoir compares well with the ranges recorded for other tropical Lakes [21,42,51]. Also, there is marked high conductivity in Apete/Elewure and Agbaje/Babalegba and this could be attributed to high influx water which contains a lot of suspended and dissolved materials. The seasonal distribution of conductivity during the period of investigation showed a narrow significant increase in wet season. Similar observation has been reported for other reservoirs in Southwestern Nigeria [22,36,42]. Ibrahim et al. [19] and Kolo and Oladimeji [24] however, reported higher conductivity in the dry season in Shiroro Lake and Kontagora Reservoir respectively. The mean range of chemical oxygen demand 
(53.40-325.00 mgl-1) showed the reservoir to be highly polluted as it significantly fell out of optimum standard recommended range for both aquatic life and drinking [32]. Higher chemical oxygen demand concentration was found in the wet season with the highest value been recorded in most part of the reservoir. The medium of high level of COD in study area could be ascribed to very large discharge of industrial effluents into the upstream of the reservoir as asserted by Mustapha [36], thus, an indication of pollution. The mean value of COD recorded in Eleyele reservoir was comparatively higher than values obtained in Karola River [58], Oyun Reservoir [36] and Moro lake [20].

In the present study, DO show a positive significant correlation with TDS, TS and phosphate. This may be due to addition of varieties of biodegradable pollutants from domestic sewage, municipality's wastes, run-off from agricultural land etc. that stimulate the growth of microorganisms which consume the dissolved oxygen for decomposition. Thus, the concentration gradually depletes. The present observation is in agreement with similar findings reported by Barat and Jha [59] and Chakraborty [60]. Total alkalinity with $\mathrm{pH}$ showed negative correlation but with $\mathrm{Cl}^{-}$showed positive correlation. This may be due to the rate of decomposition of discharged organic matters from different sources. The significant correlation between transparency, temperature and ions as revealed in this study agreed with finding of Balogun [61] in Badagry Creek. However, such relationship may be linked to low primary productivity which may have led to decrease DO concentration [62].

\section{Conclusion}

The study inferred that only few (BOD, temperature, conductivity, total alkalinity, total hardness and ions) among tested parameters in Eleyele Reservoir were consistent with desirable limits for aquatic life and drinking. Also, the physico-chemical parameters of Eleyele Reservoir showed distinct, temporal and spatial variations throughout study period. Lake water quality parameters undergo seasonal changes and values are generally higher during wet season. The present study has shown that Apete/Elewure (S1), Agbaje/Babalegba (S2) and IgunleEro/Ago-Ilaje (S5) axis are much more polluted in terms of various physico-chemical parameters such as COD and nutrients. Water from Eleyele reservoir could be classified as moderately hard in terms of total hardness and eutrophic by secchi disc depth. Crucial steps should be taken to reduce anthropogenic discharges in the Lake basin, otherwise, high levels of pollution will not only affect aquatic life but will also invite socio-economic disasters. The results obtained from the present study shall be useful in future management of the Eleyele Reservoir.

\section{References}

1. Krishnan JR (2008) Investigation on hydrobiology and water quality parameters of Periyar lake, Thekkady Kerala. Ph.D. Thesis submitted to Mahatma Ghandi University, Kerala, India.

2. Tijani $M N$, Olaleye $A O$, Olubanjo OO (2011) Impact of urbanization on wetland degradation: A case study of Eleyele Wetland, Ibadan, South West, Nigeria. Proceedings of the Environmental Management Conference, Federal University of Agriculture, Abeokuta, Nigeria.

3. Adebisi AA (1981) Analyses of the stomach contents of the piscivorous fishes of the Upper Ogun River in Nigeria. Hydrobiologia 79: 167-177.

4. Awomeso JA, Gbadebo AM, Taiwo AM, Ogunniyi IM, Ufoegbune GC, et al. (2012) Impact evaluation of urbanization on River Ona in Eleyele catchment, Ibadan, Nigeria. Glob J Human Social Sci 12: 51-57.

5. Ajani EK, Omitoyin BO (2004) Effects of some anthropogenic activities on fish species diversity in Eleyele lake, Ibadan, Nigeria. Afr J Livestock Extens 3: 13-18.

6. Anene A (2005) Condition factor of four cichlid species of a man-made in Imo state, South Eastern Nigeria. Turk J Aquatic Sci 5: 43-47.
7. Mulani SK, Mule MB, Patil SU (2009) Studies on water quality and zooplankton community of the Panchganga River in Kolhapur city. J Environ Biol 30: 455-459.

8. Olorode OA, Bamigbola EA, Ogba OM (2015) Comparative studies of some river waters in Port Harcourt based on their physico-chemical and microbiological analysis, Niger Delta Region of Nigeria. Int J Basic Appl Sci 3: 29-37.

9. Hassan AA, Jenyo-Oni A, Dauda AB (2014) Assessment of water quality Ichthyofauna and Macroflora diversity of lower Ogun river wetlands. World Fish Marine Sci 6: 101-108.

10. Akindele EO, Adeniyi IF (2013) A study of the physico-chemical water quality, hydrology and zooplankton fauna of Opa Reservoir catchment area, lle-lfe, Nigeria. Afr J Environment Sci Technol 7: 192-203.

11. Idowu EO, Ugwumba AAA, Edward JB, Oso JA (2013) Study of the seasonal variation in the physico-chemical parameters of a tropical reservoir. Greener $J$ Physical Sci 3: 142-148.

12. Onozeyi DB (2013) Assessment of some physico-chemical parameters of River Ogun (Abeokuta, Ogun State, Southwestern Nigeria) in comparison with national and international standards. Int J Aquaculture 3: 79-84.

13. lloba KI (2012) The physic-chemical characteristics and plankton of Ethiope River, Nigeria. Ph.D Thesis, Delta State University Abraka, Delta State.

14. Ogbuagu DH, Chukwuocha NAC, Okoli CG, Njoku-Tony RF (2011) Physicochemical gradients and in situ yields in pelagial primary production of the middle reaches of Imo River in Etche, South-eastern Nigeria. J Ecol Natural Environ 3: 47-53.

15. Ogunfowokan AO, Akanni MS, Ajibola RO, Ayinde FO (2011) Trophic status and physico-chemical parameters of three reservoirs in Osun State, Nigeria. Ife J Sci 13: 27-44

16. Essein-Ibok MA, Akpan AW, Udo MT, Chude AL, Umoh IA, et al. (2010) Seasonality in the physical and chemical Characteristics of mbo river, Akwa Ibom state, Nigeria. Nig J Agri Food Environ 6: 60-72.

17. Bolaji GA (2010) Hydrological assessment of water resources and environmental impact on an urban lake: a case study of Eleyele Lake catchment, Ibadan Nigeria. J Nat Sci Engineering Technol 9: 90-98.

18. Ayoola SO, Ajani EK (2009) Seasonal variation in fish distribution and physicochemical parameters of wetland areas in Oyo State, Nigeria. Int J Biol Chem Sci 3: 107-116.

19. Ibrahim BU, Auta J, Balogun JK (2009) An assessment of the physico-chemical parameter of Kontagora Reservoir, Niger State, Nigeria. Bayero J Pure Appl Sci 2: 64-69.

20. Mustapha MK (2008) Assessment of the water quality of Oyun reservoir, Offa Nigeria, using selected physico-chemical parameters. Turk J Fisheries Aqua Sci 8: 309-319.

21. Fafioye OO, Olurin KB, Sowunmi AA (2005) Studies on the physico-chemical parameters of Omi water body of Ago-Iwoye, Nigeria. Afr J Biotechnol 4: 1022 1024.

22. Mustapha MK, Omotosho JS (2005) An assessment of the physico-chemical properties of Moro Lake, Ilorin, Nigeria. Afr J Appl Zoology Environ Biol 7: 73-77.

23. Idowu RT, Inyang NM, Eyo JE (2004) The physical chemical parameters of an African Arid Zone Man-made Lake. Animal Res Int 1: 113-119.

24. Kolo RJ, Oladimeji AA (2004) Water quality and some nutrient levels in Shiroro Lake Niger State, Nigeria. J Aquatic Sci 19: 92-99.

25. Oniye SL, Ega RA, Ajanusi OJ, Agbede RIS (2002) Some aspects of the physicochemical parameters of Zaria Dam, Nigeria. J Agric Environ 11: 367-379.

26. Kareem OK, Olanrewaju AN, Osho EF, Orisasona O, Akintunde MA (1794) Growth patterns and condition factor of Hepsetus odoe (Bloch, 1794) Captured in Eleyele Lake, Southwest Nigeria. Fish Aquac J 7: 178

27. Muhammad BA, Tasneem GK, Muhammad KJ, Hassan IA, Jameel AB, et al. (2008) Evaluation of Physico-chemical Parameters of Manchar Lake Water and Their Comparison with Other Global Published Values. Pak J Analytical Environ Chem 9: 101-109.

28. ISO (2006) Water quality-sampling- Part 1: Guidance on the design of sampling programmes and sampling techniques. Geneva. ISO Standard 5667-1.

29. APHA (2005) Standard methods for the examination of water and wastewater (20th edn). Washington D.C., American Public Health Association, American Water Works Association, Water Pollution Control Federation. 
Citation: Olanrewaju AN, Ajani EK, Kareem OK (2017) Physico-Chemical Status of Eleyele Reservoir, Ibadan, Nigeria. J Aquac Res Development 8: 512. doi: 10.4172/2155-9546.1000512

30. Hach (2003) Water analysis handbook (4th edn), Vol. 2: Hach Chemical Company Ltd, Loveland, Colorado USA.

31. WHO (2006) Guidelines for Drinking- Water Quality. (3rd edn), World Health Organization, Geneva, Switzerland.

32. Boyd CE (1998) Water quality for pond aquaculture. Research and Development Series No. 43. International Center for Aquaculture and Aquatic Environments, Alabama. Agricultural Experiment Station, Auburn University Publisher, Alabama.

33. FEPA (1991) National Environmental Protection (Effluent Limitation) Regulations of 1991. Federal Environmental Protection Agency, Lagos, Nigeria.

34. Atobatele OE, Ugwumba OA (2008) Seasonal variation in the physico-chemistry of a small tropical reservoir reservoir Aiba Reservoir, Iwo, Osun State, Nigeria. Afr J Biotechnol 7: 1962-1971.

35. Ayoade AA, Fagade SO, Adebisi AA (2006) Dynamics of limnological features of two man-made lakes in relation to fish production. Afr $\mathrm{J}$ Biotechnol 510: 1013-1021.

36. Mustapha MK (2009) Limnology and fish assemblages of Oyun reservoir Offa, Nigeria. Ph.D Thesis submitted to the Department of Zoology, Faculty of Science, University of Ilorin, Ilorin, Nigeria

37. Oso JA, Fagbuaro O (2008) An assessment of the physico- chemical properties of a tropical reservoir, Southwestern, Nigeria. J Fisheries Int 3: 42-45.

38. Atobatele OE, Morenikeji OA, Ugwumba OA (2005) Spatial variation in physica and chemical parameters of benthic macro invertebrate fauna of River Ogunpa, Ibadan. Zoologist 3: 58-67.

39. Ovie SI, Bwala RL, Ajayi O (2011) A preliminary study on limnological stock assessment, productivity and potential fish yield of Omi Dam, Nigeria. Afr J Environmental Sci Technol 5: 956-963.

40. Egemen O (2011) Water quality. Ege University Fisheries Faculty Publication No. 14 , Izmir, Turkey.

41. Adjarho UB, Esenowo IK, Ugwumba AAA (2013) Physico-chemical Parameters and Macro Invertebrates Fauna of Ona River at Oluyole Estate, Ibadan, Nigeria. Research Journal of Environmental and Earth Sciences 5: 671-676.

42. Anago IJ, Esenowo IK, Ugwumba AAA (2013) The Physico-chemistry and Plankton diversity of Awba reservoir university of Ibadan, Ibadan Nigeria. Res J Environment Earth Sci 5: 638-644.

43. Ibrahim S (2009) A survey of Zooplankton diversity of Challawa River, Kano and evaluation of some of its physicochemical conditions. Bayero J Pure Appl Sci 2: $19-26$

44. Okbah MA, El-Gohary SE (2002) Physical and chemical characteristics of Lake Edku Water, Egypt. Mediterranean Marine Sci 3: 27-39.

45. Idowu EO, Ugwumba AAA (2005) Physical, chemical and benthic fauna characteristics of a southern Nigerian reservoir. Zoologist 3: 15-25.
46. Fapohunda OO, Godstates R (2007) Biometry and composition of fish species in Owena Reservoir, Ondo State, Nigeria. J Central European Agri 8: 99-104.

47. Murdoch T, Cheo M, O'Laughlin K (2001) Streamkeeper's field guide: Watershed inventory and stream monitoring methods. Adopt-A-Stream Foundation, Everett, WA

48. Kalwale AM, Savale PA (2012) Determination of physico-chemical parameters of Deoli Bhorus Dam water. Adv Appl Sci Res 3: 273-279.

49. Araoye PA (1997) Bio-ecology of a Mochokid, Synodontis schall (Bloch \& Schneider 1801) in Asa dam, llorin, Nigeria. Ph.D Thesis, University of Ibadan, Ibadan, Nigeria.

50. Wilson CP (2010) Water quality notes: Alkalinity and Hardness; University of Florida.

51. Dirican S (2015) Assessment of water quality using physico-chemica parameters of Çamlıgöze Dam Lake in Sivas, Turkey. Ecologia 5: 1-7.

52. Bera A, Bhattacharya M, Patra BC, Sar UK (2014) Ichthyofaunal diversity and water quality in the Kangsabati reservoir, West Bengal, India. Adv Zoology 1: 1-8.

53. Garg SS (2002) Seasonal fluctuation on physico-chemical parameters of River Mandakini, Chitrakoot, Indian. J Environ Protection 22: 986-991.

54. Hujare MS (2008) Seasonal variation of physico-chemical parameters in the perennial tank of Talsande, Maharashtra. Ecotoxicol Environ Mon 18: 233-242.

55. Golterman HL, Kouwe FA (1980) Chemical budgets and nutrients pathways The functioning of ecosystems. Internat Biol Programme. Cambridge University Press, UK.

56. Jayalakshmi V, Lakshmi N, Singara CMA (2011) Assessment of physicochemical parameters of water and waste waters in and around Vijayawada. In J Res Pharmaceutical Biomed Sci 2: 1041-1046.

57. Patra AK, Sengupta S, Datta T (2001) Physico-chemical properties and ichthyofauna diversity in Karala river, a tributary of Teesta river at Jalpaigur District of West Bengal, India. Int J Appl Biol Pharmaceutical Technol 2: 47-58.

58. Mandal HS, Das A, Nanda AS (2013) Study of some physicochemical water quality parameters of Karola River, West Bengal - An Attempt to estimate pollution status. Int J Environ Protection 2: 16-22.

59. Barat S, Jha $P(2002)$ Changes in the water quality and total coliform bacteria load in a streach of River Mahananda at Siliguri city, West Bengal, India. Asian J Microbiol Biotechnol Environmental Sci 4: 571-575.

60. Chakraborty D (1998) A study on the water and sediment quality as well as macro population of natural hill in the Darjeeling Hill. Indian J Environment Ecoplanning 1: 69-72.

61. Balogun KJ (2015) Effects of abiotic and biotic factors on fish productivity in Badagry creek, Nigeria. A Ph.D. Thesis submitted to Department of Aquaculture and Fisheries Management, University of Ibadan.

62. Manson CF (1991) Biology of freshwater pollution. Longman, UK 